\title{
PROCUREMENT OF ULAYAT LAND FOR SUBSIDED HOUSING DEVELOPMENT IN HARAU DISTRICT LIMA PULUH KOTA REGENCY
}

\section{PENGADAAN TANAH ULAYAT UNTUK PEMBANGUNAN PERUMAHAN BERSUBSIDI DI KECAMATAN HARAU KABUPATEN LIMA PULUH KOTA*}

\author{
Inggir Deviandari ${ }^{1}$ Kurnia Warman ${ }^{2}$ Zefrizal Nurdin $^{3}$ \\ Fakultas Hukum, Universitas Andalas, Padang \\ e-mail: inggirdeviandari@gmailcom ${ }^{1}$ \\ e-mail: kwarman@law.unand.ac.id ${ }^{2}$ \\ e-mail: zefrizalnurdin@gmail.com ${ }^{3}$
}

\begin{abstract}
Ulayat rights are the rights that owned by a legal alliance, where the citizens of the community have the right to control the land. The Regional Regulation of West Sumatra Province, Article 2 paragraph (1) Number 6 of 2008 concerning Communal Land and Its Utilization states that the main principle of customary land is permanent based on the Minangkabau traditional philosophy "jua ndak makan bali, gadai ndak makan sando" (shall not bargaining; may not be pawned). The provisions of the regulation state that ulayat land may not be traded and may not be pawned, its ownership status may not change, except for importunate situation and condition, namely maik tabujua dalam rumah (for the death of family member), gadih gadang ndak balaki (wedding), rumah gadang katirisan (misfortune), mambangkik Batang tarandam (efforts to enforce). Land acquisition for the construction of subsidized housing is not a land acquisition according to Law Number 2 of 2012 concerning Land Procurement for Public Interest. The formulation of the problems discussed are first, the process of acquiring communal land for the construction of subsidized housing in Harau District, Lima Puluh Kota Regency, secondly the land registration process after the acquisition of customary land occurs, thirdly the legal consequences of acquiring customary land used for the construction of subsidized housing in Harau District, Lima Regency. Dozens of Cities againts customary law communities. This study uses an empirical juridical approach with the aim of finding out whether the law in the book is in accordance with the law in action. The results of the research study indicate that the process of acquiring communal land for the construction of subsidized housing is carried out by buying and selling. The construction of subsidized housing is managed by a legal entity in the form of a Limited Liability Company. The status of land ownership is just as the user of the facility that called with Hak Guna Bangunan.
\end{abstract}

Keywords: Land Acquisition; Sale and Purchase; Housing Development.

\section{Abstrak}

Hak ulayat adalah hak yang dimiliki oleh suatu persekutuan hukum, dimana para warga masyarakat tersebut mempunyai hak untuk menguasai tanah. Perda Provinsi Sumatera Barat Pasal 2 ayat (1) Nomor 6 Tahun 2008 tentang Tanah Ulayat dan Pemanfaatannya, menyatakan azas utama tanah ulayat bersifat tetap berdasarkan filosofi adat Minangkabau 'jua ndak makan bali, gadai ndak makan sando. Ketentuan peraturan tersebut menyatakan tanah ulayat tidak boleh diperjualbelikan dan tidak boleh pula digadai, tidak boleh berubah status kepemilikannya, kecuali menyangkut peristiwa darurat yaitu maik tabujua ditangah rumah, gadih gadang ndak balaki, rumah gadang katirisan, mambangkik batang tarandam. Pengadaan tanah untuk pembangunan

\footnotetext{
* Naskah diterima: 16 September 2021, direvisi: 23 September 2021, disetujui untuk terbit: 29 September 2021 Doi: $10.3376 /$ jch.v7i1.416
} 
Inggir Deviandari, Kurnia Warman, Zefrizal Nurdin: Pengadaan Tanah Ulayat Untuk...

perumahan bersubsidi bukanlah merupakan pengadaan tanah menurut Undang-undang Nomor 2 tahun 2012 tentang Pengadaan Tanah Untuk Kepentingan Umum. Oleh karena itu untuk perolehan tanahnya berlakulah ketentuan peralihan secara umum seperti jual beli. Rumusan masalah yang dibahas adalah pertama, proses pengadaan tanah ulayat untuk pembangunan perumahan bersubsidi di Kecamatan Harau Kabupaten Lima Puluh Kota, kedua proses pendaftaran tanah setelah pengadaan tanah ulayat terjadi, ketiga akibat hukum pengadaan tanah ulayat yang digunakan untuk pembangunan perumahan bersubsidi diKecamatan Harau Kabupaten Lima Puluh Kota terhadap masyarakat hukum adat. Kajian ini menggunakan metode pendekatan yuridis empiris dengan tujuan untuk mengetahui apakah law in the book sudah sesuai dengan law in action. Hasil kajian penelitian menunjukkan bahwa proses pengadaan tanah ulayat untuk pembangunan perumahan bersubsidi tersebut dilakukan dengan cara jual beli. Pembangunan perumahan bersubsidi dikelola oleh badan hukum yang berbentuk Perseroan Terbatas. Status kepemilikan tanah yang akan dimiliki adalah Hak Guna Bangunan.

Kata Kunci: Pengadaan Tanah; Jual Beli; Pembangunan Perumahan.

\section{PENDAHULUAN}

Tanah memiliki arti yang sangat penting dalam kehidupan manusia, karena sebagian besar kehidupan manusia bergantung kepada tanah. Terdapat korelasi yang erat antara manusia dengan

tanah dan tidak ada satupun manusia di dunia ini yang tidak membutuhkan tanah. Mengingat tanah termasuk segala sesuatu yang melekat di atasnya menjadi bagian dari tanah, seperti pohon atau tumbuhan yang melekat pada tanah tersebut. (Mebri, 2017)

Tanah di Indonesia pada dasarnya sudah ada yang memiliki atau sudah menempati. Pentingnya tanah bagi kehidupan manusia, sehingga tidak heran dan tidak jarang jika setiap manusia ingin

memilikinya, yang bisanya menimbulkan akibat hukum atau perbedaan pendapat atau perselisihan atau bahkan pertentangan di kalangan keluarga terhadap penguasaan/pemilikan mengenai tanah, bahkan banyaknya Pemberian Ganti Rugi Terhadap Pengadaan Tanah Oleh Pemerintah Untuk Kepentingan Umum kasus sengketa batas tanah dengan hak milik, di dalam masyarakat (baik karena tidak jelasnya batas Sebelah Barat; Sebelah Timur; maupun batas Sebelah Selatan dan Sebelah Utara) (Syahri, 2014).

Istilah "menguasai" atau"dikuasai dengan dimiliki" ataupun "kepunyaan dalam konteks yuridis" mempunyai arti atau makna yang berbeda dan menimbulkan akibat hukum yang berbeda pula. Arti "dikuasai" tidak sama dengan pengertian "dimiliki". Jika menyebutkan tanah tersebut dikuasai atau menguasai dalam arti "possesion", maka makna yuridisnya adalah tanah tersebut dikuasai seseorang secara fisik yang dalam arti faktual digarap, dihuni, namun belum tentu bahwa secara yuridis dia adalah pemilik atau yang mempunyai tanah tersebut, pada umumnya hanya mampu dibuktikan hak atas tanahnya, dengan bukti nyata bahwa ia menduduki atau menguasai secara fisik tanahnya tersebut. (Farida Patittingi, 2011) Demikian juga bila menyebutkan bahwa tanah tersebut di miliki atau kepunyaan dalam arti "Ownership" memilki pengertian dalam yuridis bahwa tanah tersebut merupakan tanah milik atau kepunyaan, namun bukan 
berarti pula secara fisik menguasai tanah tersebut karena mungkin adanya hubungan kerja sama atau kontraktual tertentu. (Maria Farida Naibaho, 2015)

Ada dua hal yang menyebabkan tanah memiliki kedudukan yang sangat penting dalam hukum adat, yaitu karena sifat dan faktor dari tanah itu sendiri. Bila dilihat dari sifatnya, tanah merupakan satusatunya harta kekayaan yang bagaimanapun keadaannya, tetap masih seperti dalam keadaan semula. Hal itulah yang membuat tanah dalam hukum adat memiliki arti yang sangat penting. Begitu juga apabila kita lihat dari faktornya, tanah merupakan tempat tinggal dan memberikan kehidupan serta tempat bagi anggota persekutuan dikuburkan kelak setelah ia meninggal dunia (Dewi Wulansari, 2010).

Selanjutnya terkait dengan tanah ulayat G. Kertasapoetra dan kawankawan menyatakan: Hak ulayat adalah hak yang dimiliki oleh suatu persekutuan hukum (desa, suku), dimana para warga masyarakat (persekutuan hukum) tersebut mempunyai hak untuk menguasai tanah, yang pelaksanaannya diatur oleh ketua persekutuan (kepala suku/kepala desa yang bersangkutan) (G.Kertasapoetra, AG.Kartasapoetra, A. Setiady, 1985).

Keberadaan tanah Ulayat telah diakui oleh Undang-Undang Pokok Agraria, Pasal 3 menyatakan bahwa pelaksanaan hak ulayat dan hak-hak yang serupa itu dari masyarakat-masyarakat hukum adat sepanjang menurut kenyataannya masih ada harus sedemikian rupa sehingga sesuai dengan kepentingan nasional dan Negara yang berdasarkan atas persatuan bangsa serta tidak boleh bertentangan dengan Undang-Undang dan peraturan yang lebih tinggi. ( Ali Amran, 2017)

Sifat-sifat hak ulayat, A. Suriyaman Mustari Pide berpendapat bahwa, maksud kedalam dan keluar tersebut adalah:

1. Bersifat kedalam adalah penguasaan dan pengelolaan lahan dan segala bentuk kekayaan alam material dan non-material dikuasai oleh masyarakat adat yang bersangkutan tanpa campur tangan dari puhak luar.

2. Bersifat keluar adalah adanya kemungkinan masyarakat luar untuk mengelola dan mempergunakan tanah ulayat tersebut dengan tata karma dan etika yang dianut dalam masyarakat hukum adat, yakni berupa recoqnitie atau uang pemasukan, sebelum dilakukannya pengelolaan memungut hasil hutan dan memberikan uang pengakuan sebagai tanda terima kasih setelah memungut hasil hutan difungsikan sebagai sarana untuk memulihkan "keseimbangan magis" (A. Suriyam Mustari Pide, 2014).

Sebagaimana telah diterangkan sebelumnya, bahwa tanah ulayat bukan merupakan obyek pendaftaran tanah, akan tetapi berdasarkan ketentuan Menteri Negara Agraria/Kepala Badan Pertanahan Nasional Nomor 5 Tahun 1999 pada Pasal 4 ayat (1) dan (2) ini menyebutkan tanah ulayat dapat dikuasai oleh perseorangan dan badan hukum dengan cara didaftar sebagai hak atas tanah apabila dikehendaki oleh pemegang haknya yaitu warga masyarakat hukum adat menurut ketentuan hukum adatnya yang berlaku. 
Inggir Deviandari, Kurnia Warman, Zefrizal Nurdin: Pengadaan Tanah Ulayat Untuk...

Peraturan Menteri Agraria Nomor 10 Tahun 2016 tentang Tata Cara Penetapan Hak Komunal Atas Tanah Masyarakat Hukum Adat Dan Masyarakat Yang Berada Dalam Kawasan Tertentu menyatakan hak komunal adalah hak milik bersama atas tanah yang diberikan kepada masyarakat yang berada dalam kawasan tertentu. Sehingga dapat dikatakan hak ulayat bersifat komunalistik karena hak itu merupakan hak bersama anggota masyarakat hukum adat atas tanah yang bersangkutan.

Selanjutnya Pemerintah Daerah Sumatera Barat telah mensahkan Peraturan Daerah Nomor 6 Tahun 2008 tentang Tanah Ulayat dan Pemanfaatannya. Sebagai daerah yang masih banyak tanah ulayatnya tentu dibutuhkan peraturan daerah agar tidak terjadi konflik antar masyarakat mengenai tanah ulayat ini.

Terkait dengan tanah ulayat yang ada di Sumatera Barat, berdasarkan Peraturan Daerah Provinsi Sumatera Barat Nomor 6 Tahun 2008 tentang Tanah Ulayat Dan Pemanfaatannya menyebutkan ada 4 macam hak ulayat :

a. Tanah Ulayat Nagari

b. Tanah Ulayat Suku

c. Tanah Ulayat Kaum

d. Tanah Ulayat Rajo

Undang-Undang Nomor 2 Tahun 2012 tentang Pengadaan Tanah Bagi Pembangunan Untuk Kepentingan Umum Pasal 1 angka 2 menentukan bahwa Pengadaan Tanah adalah kegiatan menyediakan tanah dengan cara memberi ganti kerugian yang layak dan adil kepada pihak yang berhak. Pemerintah dan/atau
Pemerintah daerah dalam hal ini menjamin tersedianya tanah bagi kepentingan umum. Kemudian pihak yang berhak wajib melepaskan tanahnya pada saat pelaksanaan pengadaan tanah untuk kepentingan umum setelah pemberian ganti kerugian atau berdasarkan putusan pengadilan yang telah memperoleh kekuatan hukum tetap.

Dengan dikeluarkannya Ketentuan Pelaksanaan Peraturan Presiden Nomor 65 Tahun 2006 tentang Pengadaan Tanah Bagi Pelaksanaan Pembangunan Untuk Kepentingan Umum, menjelaskan bahwa pengadaan tanah adalah setiap kegiatan untuk mendapatkan tanah dengan cara memberikan ganti rugi kepada yang melepaskan atau menyerahkan tanah, bangunan, tanaman dan benda-benda yang berkaitan dengan tanah.

Dalam proses pengadaan proses musyawarah yang dilakukan oleh panitia pembebasan tanah dan pemegang hak ditujukan untuk memastikan bahwa pemegang hak memperoleh harga kesepakatan yang layak terhadap tanahnya. Harga kesepakatan itu dapat berupa uang, tanah pengganti (ruilslag), pemukiman kembali (relokasi) atau pembangunan fasilitas umum yang bermanfaat bagi masyarakat setempat (Andrian Sutedi, 2007).

Undang-undang Republik Indonesia Nomor 1 tahun 2011 tentang perumahan dan kawasan permukiman pasal 1 ayat 2 mendefinisikan perumahan bahwa "kumpulan rumah sebagai bagian dari permukiman, baik perkotaan maupun perdesaan, yang dilengkapi dengan prasarana, sarana dan utilitas umum 
sebagai hasil upaya pemenuhan rumah layak huni".

Peraturan Menteri Negara Perumahan Rakyat Republik Indonesia Nomor 25 Tahun 2011 Tentang Pedoman Penyelenggaraan Perumahan Murah Pasal 65 menyatukan bahwa penyediaan tanah untuk pembangunan perumahan murah dapat dilakukan melalui:

a. Pemberian hak atas tanah terhadap tanah yang langsung dikuasai oleh negara;

b. Konsolidasi tanah oleh pemilik tanah;

c. Peralihan atau pelepasan hak atas tanah oleh pemilik tanah;

d. Pemanfaatan dan pemindah tanganan tanah barang milik negara/daerah sesuai dengan ketentuan peraturan perundang-undangan;

e. Pendayagunaan tanah negara bekas tanah terlantar; dan/atau

f. Pengadaan tanah untuk pembangunan bagi kepentingan umum sesuai ketentuan peraturan perundangundangan.

Adanya pengkhususan cara pengadaan tanah melalui jual beli tersebut di atas, baik yang diatur oleh Keputusan Presiden Nomor 55 Tahun 1993, maupun yang diatur oleh Peraturan Presiden Nomor 36 Tahun 2005 jo. Peraturan Presiden Nomor 65 Tahun 2006, menimbulkan serangkaian pertanyaan mengingat Pemerintah atau Pemerintah Daerah hanya diperkenankan sebagai subyek Hak Pakai, dan dalam keadaan tertentu dapat juga sebagai pemegang Hak Pengelolaan, sedangkan tanah yang akan dipergunakan untuk pembangunan status haknya beragam tidak hanya Hak Pakai, tetapi umumnya berstatus Hak Milik, Hak Guna Usaha dan Hak Guna Bangunan, sebagaimana yang terjadi pada proyek pengadaan tanah untuk pembangunan perumahan bersubsidi di Kabupaten Lima Puluh Kota.

\section{METODE PENELITIAN}

Dalam penelitian penulis menggunakan metode pendekatan yuridis empiris, yaitu suatu pendekatan masalah melalui penelitian hukum dengan melihat peraturan hukum yang berlaku yang akan menghasilkan teori-teori tentang eksistensi dan fungsi hukum dalam masyarakat. Penelitian menekankan pada praktek dilapangan dikaitkan dengan aspek hukum atau perundang-undangan yang berlaku. Data Primer yaitu data yang berupa keterangan yang berasal dari pihak yang terlibat dengan objek yang diteliti, yaitu berupa data langsung dari masyarakat hukum adatdan data yang diperoleh di Kantor Pertanahan kabupaten Lima Puluh Kota. Data Sekunder dikumpulkan berdasarkan studi pustaka dan literature serta dokumen yang berkaitan erat dengan penelitian ini. Populasinya adalah seluruh tanah kaum yang termasuk dalam pengadaan tanah untuk pembangunan perumahan bersubsidi di Kecamatan Harau Kabupaten Lima Puluh Kota. Samplenya adalah dua kasus jual beli tanah ulayat kaum di Nagari Gurun dan Nagari Sarilamak di Kecamatan Harau Kabupaten Lima Puluh Kota. Data yang diperoleh dari penelitian ini akan 
Inggir Deviandari, Kurnia Warman, Zefrizal Nurdin: Pengadaan Tanah Ulayat Untuk...

dianalisis dengan menggunakan metode kualitatif, yaitu analisis terhadap data tanpa menggunakan rumus statistik karena data yang digunakan tidak berupa angkaangka.

\section{HASIL DAN PEMBAHASAN}

A. Proses Pengadaan Tanah Ulayat

Untuk Pembangunan Perumahan

Bersubsidi di Kecamatan Harau Kabupaten Lima Puluh Kota

Pengadaan tanah adalah setiap kegiatan untuk mendapatkan tanah dengan cara memberikan ganti rugi kepada yang melepaskan atau menyerahkan tanah, bangunan, tanaman dan benda-benda yang berkaitan dengan tanah atau dengan pencabutan hak atas tanah.

Beberapa pendapat para sarjana mengenai pengadaan tanah dikutip sebagai perbandingan, antara lain:

Perbuatan hukum yang berupa melepaskan hubungan hukum yang semula ada antara pemegang hak dan tanahnya yang diperlukan, dengan pemberian imbalan dalam bentuk uang, fasilitas atau lainnya, melalui musyawarah untuk mencapai kata sepakat antara empunya tanah dan pihak yang memerlukannya (Boedi Harsono, 1990).

Menurut John Salidentho, pengadaan tanah adalah dimaksudkan untuk menyediakan dan mengadakan tanah untuk kepentingan pemerintah dalam rangka pembangunan proyek atau pembangunan sesuai program Pemerintah yang telah ditetapkan (John Salidentho, 1988).
Sedangkan menurut Gunanegara pengadaan tanah adalah proses pelepasan hak atas kepemilikan orang atas dan/ atau benda-benda yang ada di atasnya yang dilakukan secara sukarela untuk kepentingan umum (Gunanegara, 2008).

Proses pengadaan tanah yang dilakukan oleh pemerintah tentu saja memerlukan tanah. Tanah yang terkena pengadaan tanah seringkali bersentuhan dengan tanah milik adat/tanah ulayat milik suatu masyarakat adat. Pengadaan tanah yang bersentuhan dengan tanah ulayat atau tanah adat tentunya harus juga menghormati hukum adat yang berlaku pada daerah tersebut, Pemberian ganti kerugian ataupun proses pelepasan tanah ulayat tentu saja harus menghormati hukum adat yang berlaku di daerah tersebut.

Pada prinsipnya hukum agraria Indonesia mengenal dua bentuk pengadaan tanah yaitu:

1. Dilaksanakan dengan cara pelepasan atau penyerahan hak atas tanah (pembebasan hak atas tanah): Peraturan Presiden Nomor 65 Tahun 2006 memberikan definisi pembebasan tanah adalah melepaskan hubungan hukum antara pemegang hak atas tanah dengan tanah yang dikuasainya dengan memberikan ganti rugi atas dasar prinsip penghormatan terhadap hak atas tanah melalui proses musyawarah.

2. Dilaksanakan dengan cara pencabutan hak atas tanah. Berdasarkan penjelasan umum UU Nomor 20 Tahun 1961 tentang Pencabutan Hak-Hak atas Tanah dan 
Benda-Benda yang Ada Di Atasnya, dapat dipahami bahwa sesungguhnya pencabutan hak atas tanah adalah kewenangan yang diberikan oleh undang-undang kepada pemerintah, dalam hal ini presiden. (Mohammad Mulyadi, 2017).

Pengadaan tanah bukan untuk kepentingan umum tidak diatur dalam ketentuan Pasal 10 Undang-undang tentang Pengadaan tanah, yang berlaku bagi pengadaan tanah bukan untuk kepentingan umum adalah tentang peralihan hak pada umumnya.

Definisi dialihkan menunjukkan suatu perbuatan hukum yang disengaja untuk memindahkan hak atas tanah kepada pemilik lain melalui jual beli, hibah, tukar menukar, Dan hibah wasiat. Jadi, meskipun dalam Pasal hanya disebutkan dialihkan, termasuk salah satunya adalah perbuatan hukum peralihan hak atas tanah karena jual beli. Dalam penjelasan umum UUPA dinyatakan karena bahwa hukum tanah nasional didasarkan pada hukum adat. (Febri Andiki, Sukirno, Adya Paramita Prabandari, 2019).

Pengadaan tanah tersebut tidak dapat dipaksakan perolehan tanahnya, tetapi harus berdasarkan kesepakatan pemilik tanahnya. Dimana apabila kesepakatan tersebut tidak tercapai, pencabutan hak atas tanah tersebut tidak dapat dilakukan. Sehingga proses pengadaan tanah bukan untuk kepentingan umum dapat terjadi dengan peralihan hak, seperti jual beli biasa dalam hubungan keperdataan. Berbeda dengan pengadaan tanah untuk kepentingan umum dimana perolehan tanahnya bisa dipaksakan karena ranahnya hukum publik. Dalam pengadaan tanah bukan untuk kepentingan umum hubungannya hanya keperdataan biasa yang lazim dilakukan dengan perjanjian jual beli.

Apabila tanah yang diperlukan oleh pemerintah untuk kegiatan pembangunan tersebut luasnya kurang dari 5 (lima) hektar, dapat dilakukan melalui jual beli. Hal tersebut sesuai dengan ketentuan Pasal 121 Peraturan Presiden No. 40 Tahun 2014 tentang Pengadaan Tanah Skala Kecil, yang mengatur :"Dalam rangka efisiensi dan efektivitas, pengadaan tanah untuk kepentingan umum yang luasnya tidak lebih dari 5 (lima) hektar dapat dilakukan langsung oleh instansi yang memerlukan tanah dengan para pemegang hak atas tanah, dengan cara jual-beli atau tukar menukar atau cara lain yang disepakati oleh kedua belah pihak. (Dedi Hernawan, 2015).

Proses pengadaan tanah untuk pembangunan perumahan bersubsi di Nagari Sarilamak juga dilakukan secara jual beli. Perusahan yang bertindak selaku pengembang juga merupakan PT. Multi Karya Petama (MKP), dimana tanah tersebut terlebih dahulu di sertifikatkan. Penerbitan sertifikat dilakukan dengan mengajukan permohonan penerbitan sertifikat kepada Kantor Badan Pertanahan Kabupaten Lima Puluh Kota. Dimana pihak yang ingin mengajukan permohonan penerbitan sertifikat melengkapi syarat-syarat yang telah ditetapkan oleh BPN Kabupatun Lima Puluh Kota. Terhadap tanah yang dimiliki 
Inggir Deviandari, Kurnia Warman, Zefrizal Nurdin: Pengadaan Tanah Ulayat Untuk...

oleh komunal salah satu syarat yang diperlukan adalah surat kesepakatan bersama dimana di dalam surat tersebut dibunyikan kepada siapa perwakilan nama yang dibuatkan di dalam sertifikat tersebut baik satu nama maupun beberapa nama.

Pada proses pengadaan tanah ini dilangsungkan dengan jual beli di kantor Pejabat Pembuat Akta Tanah (PPAT) Rahmat Safri, S.H.,M.Kn antara Samsul Hidayat selaku perwakilan kaumnya. Luas tanah tersebut adalah 2,6 hektar terdiri dari 132 unit dengan tipe perumahan 36 luas bangunannya 90 meter persegi dengan nama perumahan BUKIT PALANO RESIDENCE. ( Wawancara, tanggal 19 Juni 2021) Jual beli tanah tersebut seharga Rp. 535.640.000,- (lima ratus tiga puluh lima juta enam ratus empat puluh juta rupiah). Berdasarkan Akta PPAT tanggal 15 April 2021 No. 49/2021.

Berikut lampiran site plan perumahan subsidi Bukit Palano Residence:

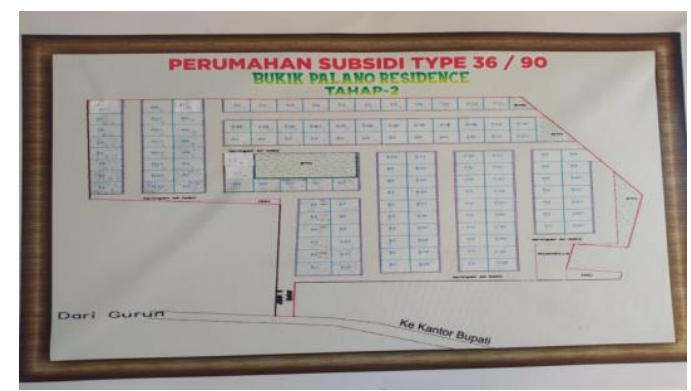

Pasal 33 ayat (1) Undang-undang Nomor 1 Tahun 2011 tentang Perumahan Dan Kawasan Pemukiman menyatakan bahwa :

1) Pemerintah daerah wajib memberikan kemudahan perizinan bagi badan hukum yang mengajukan rencana pembangunan perumahan untuk MBR.
2) Pemerintah daerah berwenang mencabut izin pembangunan perumahan terhadap badan hukum yang tidak memenuhi kewajibannya.

3) Ketentuan lebih lanjut mengenai bentuk kemudahan perizinan dan tata cara pencabutan izin pembangunan sebagaimana dimaksud pada ayat (1) dan ayat (2) diatur dengan Peraturan Menteri.

Berdasarkan penjelasan pasal 33 ayat 1 tersebut diatas, Pemerintah memberikan kemudahan perizinan kepada badan hukum dimana dalam pembangunan perumahan di sini yaitu PT MKP, dengan adanya Pasal 33 ayat 1 tersebut PT. MKP mendapatkan izin untuk rencana pembangunan perumahan bersubsi tersebut dengan mudah.

Proses perolehan tanah untuk pembangunan perumahan tersebut dilakukan dengan jual beli. Pelaksanaan nya juga dilakukan di Kantor PPAT di Kabupaten Lima Puluh Kota, dengan bapak Indra selaku Direktur yang mewakili PT. MKP yang bertindak dalam melakukan perbuatan hukum. Dengan jual beli beralih lah kepemilikan bapak Samsul Hidayat terhadap tanah tersebut kepada PT. MKP. PT. MKP sebagai badan hukum tidak dibolehkan memiliki status hak sebagai Hak milik, oleh karena itu harus dimohonkan kepada BPN untuk merubah status hak nya menjadi Hak Guna Bangunan (HGB).

Setelah HGB diberikan oleh negara maka hubungan hukumnya beralih menjadi hubungan hukum dalam lapangan hukum publik (administrasi negara) antara pengusaha dan pemerintah. Hal ini 
ditandai dengan dicantumkannya hak dan kewajiban dari pengusaha sebagai pemegang HGB di dalam surat keputusan pemberian HGB yang bersangkutan. Ketentuan seperti ini tentu saja merugikan masyarakat hukum adat, karena secara yuridis tanah ulayat mereka telah berubah status menjadi HGB. Dengan demikian, tanah ulayat masyarakat hukum adat menjadi punah setelah melalui proses pemberian HGB kepada pengusaha (Warman dan Andora, 2013).

\section{B. Proses Pendaftaran Tanah Setelah Pengadaan Tanah}

Persyaratan proses pendaftaran tanah tergantung pada status hak tanah yang akan didaftarkan tersebut, sudah bersertifikat atau belum serta cara perolehan haknya. Pendaftaran hak ulayat didasari dengan pelepasan tanah ulayat (Marlyn dan Mulyadi, 2017).

Pendaftaran tanah untuk pertama kali atau pembukuan sesuatu hak atas tanah berguna supaya kita bisa menentukan secara memuaskan siapa yang berhak atas suatu tanah serta batas-batas dari tanah itu. Pendaftaran tanah yang ada di Indonesia selain diatur dalam pasal 19 UUPA juga diatur dalam PP 24 tahun 1997. Pendaftaran diselenggarakan oleh Badan Pertanahan Nasional sesuai dengan PP 24 tahun 1997 pasal 5.

Pendaftaran tanah memberikan kepastian hukum bagi para pemegang hak atas tanah juga diatur dalam pasal 6 ayat (1) dan (2) PP 24 tahun 1997. Bunyi pasal 6 ayat (1):

1) Dalam rangka penyelenggaraan pendaftaran tanah sebagaimana dimaksud dalam pasal 5 tugas pelaksanaan pendaftaran tanah dilakukan oleh kantor pertanahan, kecuali kegiatan-kegiatan tertentu yang oleh peraturan pemerintah ini atau perundang-undangan yang bersangkutan ditugaskan kepada pejabat lain.

2) Dalam melaksanakan pendaftaran tanah, Kepala Kantor Pertanahan dibantu oleh PPAT dan pejabat lain yang ditugaskan untuk melaksanakan kegiatan-kegiatan tertentu menurut Peraturan Pemerintah ini dan peraturan Perundangan-undangan yang bersangkutan.

Pendaftaran tanah untuk pertama kali adalah kegiatan pendaftaran tanah yang dilakukan terhadap obyek pendaftaran tanah yang belum didaftar berdasarkan Peraturan Pemerintah Nomor No. 24 tahun 1997 tentang Pendaftaran Tanah. Kegiatan pendaftaran tanah untuk pertama kali dapat dilakukan dengan dua cara:

a. Pendaftaran tanah secara sistematik

Pendaftaran tanah secara sistematik adalah kegiatan pendaftaran tanah untuk pertama kali yang dilakukan secara serentak yang meliputi semua obyek pendaftaran tanah yang belum didaftar dalam wilayah atau bagian wilayah suatu desa/kelurahan.

b. Pendaftaran tanah secara sporadic

Pendaftaran tanah secara sporadik adalah kegiatan pendaftaran tanah untuk pertama kali mengenai satu atau beberapa obyek pendaftaran tanah dalam wilayah atau bagian wilayah suatu desa/kelurahan secara individual atau massal. Pendaftaran tanah secara sporadic dilaksanakan atas permintaan 
Inggir Deviandari, Kurnia Warman, Zefrizal Nurdin: Pengadaan Tanah Ulayat Untuk...

pihak yang berkepentingan. (Yohanes

Babtista Kou, 2016)

Pendaftaran ini dilakukan atas kemauan suatu individu atau masyarakat yang mempunyai kemauan untuk, mendaftarkan hak milik atas tanah yang dimilikinya dengan cara datang ke Kantor Pertanahan dimana tanah tersebut berada. Pemohon mendaftarkan tanah atas inisiatif sendiri bukan karena adanya program dari pemerintah yang dalam hal ini pendaftaran tanah secara sistematik berbeda dengan pendaftaran tanah secara sporadik.

Pendaftaran peralihan hak atas tanah yang dilaksanakan di Kantor Pertanahan Kabupaten Lima Puluh Kota, mengacu pada pasal 23 ayat (1) UUPA disebutkan bahwa hak milik demikian juga dengan peralihannya, hapusnya dan pembebanannya dengan hak-hak ini wajib didaftarkan menurut ketentuan Pasal 19 UUPA, peralihan hak milik atas tanah tersebut dapat bermacam-macam bentuk antara lain salah satunya adalah dengan cara jual beli, oleh karena itu peralihan hak milik atas tanah karena jual beli wajib didaftarkan menurut ketentuan Pasal 19 UUPA tersebut.

Pelaksanaan pendaftaran peralihan hak atas tanah dengan cara jual beli di Kantor Pertanahan Kabupaten Lima Puluh Kota, pemohon tidak datang langsung ke Kantor Pertanahan. Tetapi, pendaftaran peralihan haknya diwakilkan oleh PPAT. Hal ini, disebabkan karena selain PPAT bertugas membuat akta jual beli tanah, PPAT juga bertugas mendaftarkan peralihan haknya pada kantor pertanahan setempat yang selambat-lambatnya 7 hari sejak ditandatanganinya akta jual beli hak atas tanah tersebut. Sebelum melakukan peralihan hak milik atas tanah dengan cara jual beli, PPAT yang bersangkutan wajib melakukan pemeriksaan mengenai keaslian sertifikat ke Kantor Pertanahan.

Proses penyertifikatan tanah setelah pengadaan untuk pembangunan perumahan bersubsidi diwakilkan oleh PPAT yang ditunjuk oleh PT. MKP mewakili para pembeli perumahan tersebut untuk melakukan peralihan hak antara PT.MKP kepada pembeli perumahan. Sertifikat yang mulanya berstatus HGB atas nama PT. MKP dilakukan pemecahan sertifikat terlebih dahulu di kantor BPN dimana sertifikat yang luasnya nya 2,6 hektar dipecah menjadi 132 sertifikat dengan masingmasing luas 90 meter persegi. Setelah dipecah terbitlah 132 sertifikat atas nama PT.MKP, sertifikat yang di atasnya ada bangunan rumah type 36 dengan luas 90 meter persegi tersebut yang dijual kepada perorangan. Setelah adanya pembeli yang menginginkan rumah bersubsidi tersebut makan dilakukan akad kredit dengan pihak bank selaku pihak ketiga sebagai penyedia dana, dimana pembeli akan melakukan pembayaran berupa angsuran kepada pihak bank tersebut. Pada proses akad kredit tersebut juga dihadirkan PPAT, dimana proses penandatanganan Akta Jual Beli nya dilangsungkan pada saat akad kredit tersebut. Setelah penandatanganan Akta Jual Beli antara pembeli dengan PT. MKP maka PPAT selaku pejabat yang berwenang melanjutkan proses peralihan tersebut kepada BPN, berikut seluruh persyaratan 
yang telah di mintakan sebelum nya seperti KTP Pembeli, Kartu Keluarga, NPWP, dan persyaratan surat kuasa, surat pernyataan yang telah ditanda tangani. Proses peralihan tersebut kemudian dilanjutkan oleh PPAT kepada BPN, berkas tersebut diproses dengan melakukan pengecekan sertifikat terlebih dahulu, setelah proses administrasi selesai baik dengan bukti pembayaran Bea Perolehan Hak Atas Tanah (BPHTB) maupun pembayaran Pajak Penghasilan telah diverifikasi maka proses peralihan tersebut dilanjutkan, setelah di teliti semua berkas dan dinyatakan lolos verifikasi maka terbitlah sertifikat HGB atas nama pembeli.

Status sertifikat HGB memiliki batas waktu maksimal 30 tahun dan dapat diperpanjang 20 tahun. Untuk dapat mengajukan permohonan Hak Milik atas tanah untuk rumah tinggal, maka pemohon harus mengetahui terlebih dahulu pembatasan pemberian Hak Milik untuk rumah tinggal. Adapun pembatasan Hak Milik tersebut adalah:

1. Untuk setiap bidang tanah yang dimohon, luasnya tidak boleh lebih dari 2000 M2. Dalam pasal 4 ayat 2 Keputusan Menteri Negara Agraria / Kepala Badan Pertanahan Nasional N0. 6 Tahun 1998 ditetapkan pembatasan permohonan Hak Milik atas tanah Negara, yaitu tidak lebih dari 2000 M2. Pembatasan ini hanya berlaku untuk permohonan Hak Milik untuk tanah yang seluruhnya atau utamanya dipergunakan untuk rumah tinggal, dan tidak berlaku untuk pemberian Hak Milik di daerah pedesaan yang penggunaan tanahnya selain untuk rumah tinggal juga untuk pekarangan atau kebun.

2. Setiap pemohon dibatasi pemilikan Hak Milik atas tanah untuk rumah tinggal tidak boleh dari 5 (lima) bidang. Untuk itu, permohonan Hak Milik itu yang bersangkutan akan mempunyai Hak Milik atas tanah untuk rumah tinggal tidak lebih dari 5 (lima) bidang dan seluruhnya meliputi luas tidak boleh lebih dari 5000 M2.

Pernyataan ini berfungsi sebagai pemberian keterangan resmi dari pemohon yang akan mempunyai akibat hukum apabila di kemudian hari ternyata keterangan itu tidak benar atau palsu.

Untuk mengetahui proses pemberian Hak Milik atas tanah yang masih berstatus Hak Guna Bangunan menjadi rumah tinggal harus memperhatikan hal- hal sebagai berikut: (Lamhot Herianto Sigiro, 2017)

a. Pemohon Harus mengisi surat permohonan Hak Milik atas tanah untuk rumah tinggal di Kantor Pertanahan Kabupaten Lima Puluh Kota yang diajukan secara tertulis kepada Kepala Kantor Pertanahan yang daerah kerjanya meliputi letak tanah yang bersangkutan.

b. Pemohon juga harus melampirkan sertifikat tanah yang bersangkutan dalam permohonan peningkatan hak atas tanah dari Hak Guna Bangunan menjadi Hak Milik karena sertifikat tersebut dapat memberikan kepastian hukum kepada pemegang hak yang 
Inggir Deviandari, Kurnia Warman, Zefrizal Nurdin: Pengadaan Tanah Ulayat Untuk...

bersangkutan dan sebagai alat bukti yang sah dalam kepemilikannya.

c. Bukti yang harus disertakan dalam penggunaan tanah untuk rumah tinggal berupa:

1. Mencantumkan foto copy Izin Mendirikan Bangunan dari Instansi yang berwenang yang menerangkan bahwa bangunan tersebut telah digunakan untuk rumah tinggal

2. Surat keterangan dari Kepala Desa atau Kelurahan letak tanah setempat yang menerangkan bahwa bangunan tersebut digunakan untuk rumah tinggal.

3. Permohonan harus disertai dengan melampirkan foto copy Surat Pemberitahuan Pajak Terhutang (SPPT) dan foto copy Pajak Bumi dan Bangunan (PBB)

4. Untuk pemberian Hak Milik atas tanah untuk rumah tinggal, identitas pemohon yang digunakan pemohon agar diperiksa tentang kepemilikan tanah yang dimohonkan tersebut. Keterangan tersebut terdapat dalam sertifikat yang dimohonkan peningkatan haknya.

5. Adanya bukti perolehan hak atas tanah dan bangunan dimana bangunan tersebut berdiri.

6. Setelah semua dokumen yang diperlukan sudah lengkap, maka dokumen diserahkan ke loket II (Loket penerimaan dan penyerahan surat yang bersifat teknis) dimana petugas melakukan penelitian dokumen yang diterima. Dokumen yang diteliti adalah kelengkapan yang menjadi syarat dalam permohonan Hak Milik atas tanah untuk rumah tinggal.

7. Setelah selesai di loket II, pemohon datang ke loket III untuk melakukan pembayaran terhadap permohonan Hak Milik atas tanah. Petugas loket III bertugas melakukan pembayaran permohonan tersebut.

8. Kasubsi Pendaftaran Hak dan Informasi ( PHI ) bertugas untuk meneliti dokumen. Dokumen yang diteliti adalah mengenai nama pemohon yang tertera dalam Identitas, apakah sama dengan yang terdapat pada sertifikat Hak Guna Bangunan (HGB). Apabila terdapat perbedaan nama, maka pemohon diharuskan mencantumkan keterangan pernyataan dari pemohon yang diketahui oleh Kepala Desa setempat. Setelah itu membuat disposisi atau membuat konsep buku tanah dan sertifikat baru serta mencoret buku tanah dan sertifikat lama

9. Setelah disetujui oleh Kasubsi (PHI), maka dokumen dan konsep tanah serta sertifikat baru diserahkan kepada Kepala Seksi Pengukuran dan Pendaftaran Tanah (P\&PT) untuk meneliti dokumen dan buku tanah sertifikat baru. Apabila telah disetujui, maka Kepala Seksi 
Pengukuran dan Pendaftaran Tanah akan membubuhkan paraf pada buku tanah dan sertifikat baru tersebut, dan selanjutnya diteruskan ke Kepala Kantor Pertanahan.

10. Kepala Kantor Pertanahan bertugas meneliti kelengkapan dan kebenaran berkas permohonan serta memeriksa dokumen dan konsep buku tanah dan sertifikat baru. Apabila telah disetujui, maka Kepala Kantor Pertanahan membubuhi paraf pada buku tanah dan sertifikat baru. Selanjutnya Kepala

11. Kantor menyerahkan dokumen dan buku tanah serta sertifikat kepada petugas pelaksana subsi PHI.

12. Petugas pelaksana subsi PHI mengadakan pembukuan, selanjutnya menyerahkan dokumen kepada petugas loket III untuk melakukan pembukuan. Selanjutnya menyerahkan dokumen tersebut pada petugas loket IV.

13. Petugas loket IV mempunyai tugas untuk membukukan daftar penyerahan hasil pekerjaan dan mencatat nomor pada sertifikat. Apabila sudah lengkap maka petugas menyerahkan dokumen yang harus diarsipkan kepada petugas arsip, serta menyerahkan sertifikat kepada pemohon.

Untuk biaya yang harus dibayar oleh pemohon dalam mengajukan Peningkatan
Hak Milik dari Hak Guna Bangunan adalah sebagai berikut:

a. Untuk pemberian Hak Milik dengan Keputusan ini harus dibayar uang pemasukan kepada Negara yang ditetapkan berdasarkan ketentuan yang berlaku, yaitu Peraturan Menteri Negara Agraria/Kepala Badan Pertanahan Nasional No. 4 tahun 1998 tentang Pedoman Penetapan Uang Pemasukan, dalam Pemberian Hak Atas Tanah Negara yang berlaku tanggal 1 Juli 1998. Menurut ketentuan tersebut untuk pemberian Hak Milik atas tanah yang luasnya 600 M2 atau kurang uang pemasukannya adalah $(1 \%$ atau 0 rupiah).

b. Nilai Jual Objek Pajak ( NJOP) yang digunakan dalam menghitung uang pemasukan tersebut adalah Nilai Jual Objek Pajak ( NJOP ) pada tanggal permohonan pendaftaran, yang dapat diketahui dari SPPT PBB yang copynya disertakan pada permohonan pendaftaran Hak Milik atas tanah yang luasnya 600 M2 atau kurang, yaitu bidang tanah yang uang pemasukannya ditetapkan lebih dari pada $0 \%$. Untuk keperluan ini diberikan ketentuan sebagai berikut :

1. Permohonan pendaftaran Hak Milik yang disampaikan sesudah tanggal perhitungan uang pemasukannya dilakukan berdasarkan NJOP yang tercantum dalam SPPT PBB tahun yang bersangkutan

2. Permohonan pendaftaran Hak Milik yang disampaikan sebelum 
Inggir Deviandari, Kurnia Warman, Zefrizal Nurdin: Pengadaan Tanah Ulayat Untuk...

\begin{tabular}{lrr} 
tanggal perhitungan uang & dilakukan \\
pemasukannya & \multicolumn{2}{r}{ dong } \\
berdasarkan $\quad$ NJOP & yan \\
tercantum dalam & SPPT & PBB \\
tahun sebelumnya. & &
\end{tabular}

Untuk pendaftaran Hak Milik ini harus dibayar biaya pembuatan sertifikat menurut Peraturan Kepala Badan Pertanahan Nasional N0. 2 Tahun 1992 Tentang biaya pendaftaran tanah. Oleh karena itu pemberian Hak Milik dengan keputusan ini merupakan perubahan hak dari Hak Guna Bangunan ( baik yang masih berlaku maupun yang sudah habis jangka waktunya ) dan tidak ada perubahan nama pemegangnya, maka atas perolehan Hak Milik itu tidak dikenakan Bea Perolehan Hak Atas Tanah dan Bangunan.

Jika dikaitkan dengan teoti kepastian hukum yang dikemukakan oleh Salim yang mengatakan bahwa:

Dalam mencapai tujuan itu hukum tersebut bertugas membagi hak dan kewajiban antar perseorangan di dalam masyarakat, membagi wewenang yang mengatur cara memecahkan masalah hukum serta memelihara kepastian hukum.

Sesuai dengan penjelasan teori kepastian hukum menurut salim tersebut kepastian hukum dapat kita lihat dalam proses pendaftaran tanah ulayat sehingga memilki status hak milik. Kemudian status hak milik tersebut juga dapat diubah status hak nya salah satu yaitu Hak Guna Bangunan. Oleh karena telah diajukan permohonan perolehan status tanah ulayat tersebut maka bukti kepastian hukum tersebut adalah berupa sertifikat.

\section{Akibat Hukum Pengadaan Tanah Ulayat Yang Digunakan Untuk Pembangunan Perumahan Bersubsidi di Kecamatan Harau Kabupaten Lima Puluh Kota Terhadap Masyarakat Hukum Adat}

Pemegang Hak Ulayat adalah masyarakat adat. Ada yang territorial, karena para warganya bertempat di wilayah yang sama, seperti Nagari di Minangkabau. Ada pula genealogik, yang para warganya terikat oleh pertalian darah, seperti suku dan kaum. Sedangkan yang menjadi objek Hak Ulayat adalah tanah dalam wilayah masyarakat hukum adat territorial yang bersangkutan.( Indah Sari, 2020).

Kekuasaan persekutuan atau masyarakat hukum adat atas tanah adalah komunal/bersama sehingga perpindahan hak milik adat atas tanah tersebut kepada orang lain tidak diperbolehkan, sesuai dengan pepatah Minangkabau terhadap Harta Pusako Tinggi Kaum di jua indak dimakan bali, digadai idak di makan sando", kecuali dalam hal mengadai, ada 4 (empat) syarat, yaitu:

1. Gadih gadang indak balaki

2. Rumah gadang katirisan

3. Maik (mayat) tbujua di ateh rumah

4. Mambangkik batang tarandam (Nova Yarsina, 2018)

Berdasarkan ketentuan diatas, empat peristiwa tersebut adalah peristiwa darurat. Menurut adat Minang transaksi jual beli tanah ulayat tersebut hanya berlaku terhadap ketentuan peristiwa darurat tersebut. Jual beli tanah ulayat kaum di Nagari Gurun dan Sarilamak 
kepada PT. MKP tidak memenuhi persyaratan peristiwa darurat tersebut diatas.

Menurut Pasal 2 ayat (1) Peraturan Daerah Provinsi Sumatera Barat Nomor 6 Tahun 2008 tentang Tanah Ulayat dan Pemanfaatannya, menyatakan: "Azas utama tanah ulayat bersifat tetap berdasarkan filosofi adat Minangkabau "jua ndak makan bali, gadai ndak makan sando"

Ketentuan Pasal 2 ayat (1) tersebut jua ndk dimakan bali, gadai ndak dimakan sando menurut hukum Adat Minangkabau dijual tak dimakan beli artinya terjual sekalipun tidak dianggap terjual. Faktanya tanpa keadaan darurat apabila Kaum sepakat untuk menjual sulit untuk memulihkan kembali menjadi hak ulayat walaupun sebetulnya tidak terjadi peristiwa darurat.

Berdasarkan Peraturan Daerah Provinsi Sumatera Barat Nomor 6 Tahun 2008 tentang Tanah Ulayat dan Pemanfaatannya apabila investor telah selesai menggunakan tanah ulayat, tanah tersebut bisa dipulihkan kembali, "kabau tagak, kubangan tingga". Status HGB yang diberikan kepada konsumen yang membeli perumahan mempunyai batasan waktu, dan apabila telah mencapai batas waktu tersebut tanah akan kembali menjadi tanah ulayat, jawabannya sulit, karena semua anggota kaum telah sepakat untuk menjual.

Keputusan Menteri Negara Agraria/Kepala Badan Pertanahan Nasional Nomor 9 Tahun 1997 Tentang Pemberian Hak Milik Atas Tanah Untuk Rumah Sangat Sederhana (RSS) dan
Rumah Sederhan (RS). Pada bagian Umum Pasal I keputusan ini disebutkan bahwa yang dimaksud dengan:

1. Hak Guna Bangunan Induk adalah Hak Guna Bangunan atas tanah yang kemudian dipecah menjadi bidangbidang tanah yang lebih kecil atau sebagiannya dipisahkan untuk didaftar sebagai bidang tanah tersendiri.

2. Perubahan hak adalah penetapan Pemerintah mengenai penegasan bahwa sebidang tanah yang semula dipunyai dengan Hak Guna Bangunan, atas permohonan pemegang haknya menjadi tanah negara dan sekaligus memberikan tanah tersebut kepadanya dengan Hak Milik.

3. Hak pengelolaan adalah hak menguasai dari Negara yang kewenangan pelaksanaannya sebagian dilimpahkan kepada pemegangnya.

Yang perlu digaris bawahi dalam pasal tersebut adalah pasal 1 ayat (1) dan (2), artinya ayat (1) dapat dimaknai bahwa seorang pengembang yang membeli tanah dengan status hak milik yang akan dipergunakan untuk perumahan maka status tanah tersebut diturunkan menjadi hak guna bangunan dan dijual atau dipecah menjadi lebih kecil-kecil dan menjadi bagian tersendiri dan mempunyai nama pemegang sendiri sampai diajukan perubahan hak dari hak guna bangunan menjadi hak milik (Warman dan Andora, 2013). Atau bisa dimaknai tanah dengan sertifikat HGB juga diperoleh dari pembelian rumah baru dari developer. 
Inggir Deviandari, Kurnia Warman, Zefrizal Nurdin: Pengadaan Tanah Ulayat Untuk...

Karena developer adalah badan hukum yang tidak diperbolehkan memiliki tanah dengan status Hak Milik, walaupun pada awalnya developer membeli tanah dengan status Hak Milik dari masyarakat.

Penjelasan umum dalam UUPA menerangkan bahwa dilarangnya badan hukum mempunyai hak milik, karena memangnya badan hukum tidak periu mempunyai hak milik tetapi cukup bagi keperluan-keperluan yang khusus yaitu hak-hak lain selain hak milik ( Indah Mahnisari, 2013).

Dalam prosesnya, tanah dengan status SHM tersebut harus diturunkan dulu haknya menjadi Hak Guna Bangunan baru dilakukan jual beli dan balik nama ke atas nama developer. Sedangkan untuk ayat (2) dapat diartikan bahwa perubahan yang dengan tanah seperti yang dijelaskan dalam ayat (1) tersebut dapat dimohonkan perubahan hak yang status dulunya dari Hak Guna Bangunan dalam prosesnya menjadi tanah Negara, setelah itu diajukan menjadi hak milik. Dengan kata lain, developer menjual rumah dengan status Hak Guna Bangunan kepada konsumen dan mempersilahkan konsumen sendiri yang mengurus peningkatan hak tersebut.

Menurut Teori Kepastian, pengertian kepastian tersebut dapat dimaknai bahwa ada kejelasan dan ketegasan terhadap berlakunya hukum di dalam masyarakat. Hal agar tidak menimbulkan banyak salah tafsir. Dalam penulisan ini kepastian hukum dapat dilihat berdasarkan status kepemilikan sertifikat Hak Milik. Hak Milik adalah status kepemilikan paling kuat tanpa campur tangan atau kemungkinan dipunyai oleh pihak lain.
Oleh karena itu apabila konsumen telah melakukan perubahan status HGB menjadi Hak Milik, secara hukum status hak ulayat tidak dapat dipulihkan kembali.

\section{SIMPULAN}

1. Hasil penelitian menunjukan bahwa Proses Pengadaan Tanah Ulayat Untuk Pembangunan Perumahan Bersubsidi di Kecamatan Harau Kabupaten Lima Puluh Kota di dilakukan dengan cara jual beli. Proses jual beli tanah dilakukan di kantor Pejabat Pembuat Akta Tanah (PPAT). Jual beli merupakan proses yang sah yang menyatakan peralihan tanah dari pemilik Sertifikat. Dalam hal ini PT. Multi Karya Pertama selaku badan hukum tidak boleh memiliki sertifikat hak milik, oleh karena itu harus dimohonkan kepada Badan Pertanahan Negara untuk dilakukan perubahan statusnya menjadi Hak Guna Bangunan (HGB).

2. Pendaftaran peralihan hak atas tanah yang dilaksanakan di Kantor Pertanahan Kabupaten Lima Puluh Kota. Pelaksanaan pendaftaran peralihan haknya diwakilkan oleh PPAT. Hal ini, disebabkan karena selain PPAT bertugas membuat akta jual beli tanah, PPAT juga bertugas mendaftarkan peralihan haknya pada kantor pertanahan setempat yang selambat-lambatnya 7 hari sejak ditandatanganinya akta jual beli hak atas tanah tersebut.

3. Akibat hukum pengadaan tanah ulayat yang digunakan untuk pembangunan perumahan bersubsidi di Kecamatan Harau Kabupaten Lima 
Puluh Kota. Menurut adat Minang transaksi jual beli tanah ulayat tersebut hanya berlaku terhadap ketentuan peristiwa darurat tersebut. Jual beli tanah ulayat kaum di Nagari Gurun dan Sarilamak kepada PT. MKP tidak memenuhi persyaratan peristiwa darurat tersebut diatas. Tetapi dengan telah sepakatnya semua anggota kaum untuk menjual, secara sah tanah ulayat kaum tersebut tidak dapat dipulihkan kembali menjadi menjadi hak ulayat.

\section{UCAPAN TERIMAKASIH}

Terima kasih kepada bapak Pembimbing yang telah membantu saya dalam menyelesaikan penelitian ini. Atas masukan dan bantuan beliau akhirnya penelitian ini dapat terselesaikan, kemudian kepada seluruh rekan-rekan yang membantu dalam penelitian ini selama studi di Magister Kenotariatan Fakultas Hukum Universitas Andalas.

\section{DAFTAR PUSTAKA}

Ali Amran, 2017. Penyelesaian Sengketa Tanah Ulayat Melalui Lembaga Adat Di Minangkabau Sumatera Barat. Jurnal Hukum Acara Perdata ADHAPER, Vol. 3, No. 2

A.Suriyaman Mustari Pide, 2014, Hukum Adat Dahulu, Kini, dan Akan Datang, Prenadamedia Group, Jakarta.

Boedi, Harsono, 1999, Hukum Agraria Sejarah Pembentukan Undangundang Pokok Agraria, Isi dan Pelaksanaannya, Djambatan: Jakarta

Dedi Hernawan, 2015. Pengadaan Tanah Dengan Cara Jual Beli Oleh Instansi Pemerintah Menurut Pasa 33 Ayat
(3) UUD 1945. Jurnal Litigasi, 16(1),

ttp://dx.doi.org/10.23969/litigasi.v1 $6 i 1.53$

Dewi Wulansari, 2010, Hukum Adat Indonesia Suatu Pengantar, PT. Refika Aditama : Bandung

Farida Patittingi. 2011. Penegasan Alas

Hak Penguasaan Fisik

Turuntemurun Dalam Praktik

Pendaftaran Tanah. Jurnal Amanna Gappa. Vol. 19. No. 4.

Febri Andiki, Sukirno, Adya Paramita Prabandari, 2019. Peralihan Hak Tanah Ulayat Di Kabupaten Dharmasraya. Jurnal Notarius, V12, No 2.

G. Kertasapoetra, Setiady, 1985, HukumTanah, Jaminan UndangUndang Pokok Agraria Bagi Keberhasilan Pendayagunaan Tanah, Binaaksara, Jakarta.

Gunanegara, 2008, Rakyat dan Negara Dalam Pengadaan Tanah Untuk Pembangunan, PT. Nusa Tata: Jakarta

Indah Mahniasari, 2013. Pendaftaran Tanah Adat. Jurnal Hukum Al-Adl, http://dx.doi.org/10.31602/aladl.v5i9.187

Indah Sari, 2020. Hak-hak Atas Tanah Dalam Sistem Hukum Pertanahan Di Indonesia Menurut Undangundang Pokok Agraria (UUPA). https://journal.universitassuryadar ma.ac.id/index.php/jmm/article/dow nload/492/457

John Salondeho, 1988, Masalah Tanah dalam Pembangunan, Sinar Grafika: Jakarta

Lamhot Herianto Sigiro, 2017. Analisis Hukum Tentang Pendaftaran Tanah Ulayat Yang Menjadi Hak Perorangan Pada Tanah Ulayat Di 
Inggir Deviandari, Kurnia Warman, Zefrizal Nurdin: Pengadaan Tanah Ulayat Untuk...

Kabupaten Dairi. Premise Law Jurnal,

11.

https://media.neliti.com/media/publi cations/164919-ID none.pdf

Mebri. Kedudukan Hak Atas Tanah Masyarakat Hukum Adat Untuk Kepentingan Umum). DiH Jurnal Ilmu Hukum Edisis Februari 2017.

Maria Farida Naibaho. 2015. Pengakuan Penguasaan dan Pendudukan Tanpa Alas Hak Kepemilikkan Yang Berakibat Sengketa; Studi Kasus Putusan MA No. 2511/K/PDT/1995 Tanggal 09 September 1997. Jurnal Universitas Sumatera Utara, Vol. VIII.

Marlyn dan Mulyadi, 2017. Analisis Sosio-Yuridid Hak Ulayat Dengan Pelepasan Adat Sebagai Syarat Pendaftaran Tanah Pada Suku Marind Di Kabupaten Merauke. Jurnal Restorative Justice Vol 1, No 1.

Mohammad Mulyadi, 2017. Implementasi Kebijakan Pengadaan Tanah Untuk Kepentingan Umum Di Jakarta Utara. Jurnal Masala-masalah Sosial, $\quad$ Vol $\quad 8, \quad$ No

2,https://doi.org/10.46807/aspirasi. v8i2.1262

Novita, C. F, 2014. Tinjauan Hukum Terhadap Jual Beli Tanah Tanpa Akta PPAT (Wilayah Kecamtan Tinombo). Jurnal Ilmu Hukum Legal Opinion, 3 (2). Retrieved from https://media.neliti.com/media/publi cations/152126-ID-none.pdf

Nova Yarsina, 2018. Perlindungan Hukum Terhadap Tanah Ulayat Yang Telah Bersertifikat Di Kota Bukittinggi. Jurnal Cendikia Hukum, http://doi.org/10.33760/jch.v3i2.25
Syahri, R. A, 2014. Perlindungan Hukum Kepemilikan Hak Atas Tanah. Jurnal Ilmu Hukum Legal Opinion, 5(2). Retrieved from https://media.neliti.com/media/publi cations/146453-ID-perlindunganhukum-kepemilikan-hak-atas.pdf

Warman dan Andora, 2013. Pola Hubungan Hukum dan Pemanfaatan Tanah Ulayat di Sumatera Barat. Bagian Hukum Agraria dan Bagian Hukum Administrasi Negara Fakultas Hukum Universitas Andalas. Universitas Andalas : Padang. Jurnal Mimbar Hukum, 26(3)

https://doi.org/10.22146/jmh.16031

Yohanes Babtista Kou, 2016. Pendaftaran Tanah Secara Sistematis Terhadap Tanah Bekas Hak Adat Di Kecamatan Cibal Kabupaten Manggarai Setelah Berlakunya

PP 24 Tahun 1997 Tentang Pendaftaran Tanah. http://ejournal.uajy.ac.id/11061/1/JURNAL .$p d f$ 